\title{
Examination of Chitinolytic Bacteria in Alginate-Chitosan Encapsulation on Chili Seed Against Damping off Caused by Fusarium oxysporum
}

\author{
${ }^{1,2}$ Dwi Suryanto, ${ }^{1}$ Affan Indarwan and ${ }^{2}$ Erman Munir \\ ${ }^{1}$ Research Center for Environment and Population Issues, \\ ${ }^{2}$ Department of Biology, Faculty of Mathematics and Natural Sciences, \\ University Sumatera Utara, Medan, 20155, Indonesia
}

Received 2012-06-15, Revised 2012-11-10; Accepted 2012-12-05

\begin{abstract}
One alternative in biological control of plant pathogenic fungi is to provide biological agent inoculant in coated seed. This study was to evaluate potential control and viability of two chitinolytic bacteria, Enterobacter sp. BK15 and Bacillus sp. BK17 of alginate-chitosan encapsulation coated on chili seed against damping off caused by Fusarium oxysporum. Chili seed beads were stored at refrigerator and room temperature. Examination of the bacteria ability in reducing seedling off was conducted by growing and treating the seed beads with $F$. oxysporum inoculum. Bacterial cell viability was measured by growing grinded chili bead in minimum salt medium with chitin as sole $\mathrm{C}$ source. Re-isolation of infected seedling was done by growing it in potato dextrose agar. The result showed that the bacteria in alginate-chitosan coated seeds reduced chili damping off. Chili seedling height and dry-weight did not differ with those of (-) control, treatment with no bacterial and fungal inoculation and differed with $(+)$ control, treatment of fungal inoculation only. Re-isolation of infected seedling showed similar fungal characterization of inoculated $F$. oxysporum. Bacterial cell viability decreased significantly in 30 days of storage both at refrigerator and room temperature. However, cell viability stored at refrigerator was higher rather than that of room temperature.
\end{abstract}

Keywords: Bacillus sp., Biological Control, Coated Seed, Enterobacter sp., Seedling Off

\section{INTRODUCTION}

In controlling plant pathogenic fungi, synthetic agrochemical fungicide has mainly been used. However, it caused pathogen resistance to the chemical and environmental problems and harm to non-target organism including human. Based on their nature, many biological agents have been evaluated in order to prevent and control diverse plant pathogens, given that these options are more ecofriendly (Compant et al., 2005; Anitha and Rabeeth, 2010). Biological control agent has been applied through vegetative cells or spores, metabolites and cell immobilization/encapsulated matrix.

Encapsulating the living cells using biocompounds protect the microorganisms against many environmental stresses (Hernandez-Suarez et al., 2011), so that they can be stored dry at ambient temperatures for prolonged periods (Kasra-Kermanshahi et al., 2010). Several experimental formulations based on polymers have been evaluated (Bashan, 1998). Rokka and Rantamaki (2010) reviewed the use of several polymer gels such as chitosan, carrageenan, gum arabic, gellan gum or mesquite seed gum, gelatin and other biopolymers to encapsulate probiotic bacteria. Among these materials alginate is the most common polymer material for the encapsulation of microorganisms (Rokka and Rantamaki, 2010). These inoculants can be amended with nutrients such as chitosan to improve the short-term survival of the bacteria upon inoculation (Anitha and Rabeeth, 2010).

One of the most devastating diseases in crop and other plants throughout the world is Fusarium wilt (Anitha and

Corresponding Author: Dwi Suryanto, Research Center for Environment and Population Issues, Universitas Sumatera Utara, Medan, 20155, Indonesia Tel: +62618223564 
Rabeeth, 2010; Gupta et al., 2011). It causes extensive commercial losses by reducing both quality and yield (Anitha and Rabeeth, 2010; Gangadara et al., 2010). Fusarium is a common phytopathogenic fungus causing Fusarium wilt in chili, tomato, potato, tobacco and banana, infecting the plant seeds as soil-borne disease (Kavraulakis et al., 2010; Gupta et al., 2011; Sun et al., 2011).

Based on the need of the use of antagonist microorganisms for biological control of pathogenic fungi like $F$. oxysporum, this study was carried out. This study was to know ability of chitinolytic bacteria of Gram-negative Enterobacter sp. BK15 and of Grampositive Bacillus sp. BK17 to control Fusarium wilt in form of chili seed coated with bacterial alginate and with chitosan as amended nutrient encapsulation and to evaluate bacterial viability in the seed stored at refrigerator and room temperature.

\section{MATERIALS AND METHODS}

\subsection{Microbial Isolates and Chili Seeds}

Chitinolytic bacteria Enterobacter sp. BK15, Bacillus sp. BK17 and Fusarium sp. used in this study are collection of Microbiology Laboratory, Department of Biology, Faculty of Mathematics and Natural Sciences, Universitas Sumatera Utara, Medan Indonesia. The bacterial isolates were kept in a modified salt medium (0.7 g K $\mathrm{HPO}_{4}, 0.3 \mathrm{~g} \mathrm{KH}_{2} \mathrm{PO}_{4}, 0.5 \mathrm{~g} \mathrm{MgSO}_{4} .7 \mathrm{H}_{2} \mathrm{O}, 0.01$ g $\mathrm{FeSO}_{4} .7 \mathrm{H}_{2} \mathrm{O}, 0.001 \mathrm{~g} \mathrm{ZnSO}_{4}$ and $0.001 \mathrm{~g} \mathrm{MnCl}_{2}$ in $\left.1.000 \mathrm{~mL}^{-1}\right)$ containing $2 \%(\mathrm{w} / \mathrm{v})$ chitin colloidal (MSMC) agar, with a pH of 6.8, while Fusarium sp. was maintained in Potato Dextrose Agar (PDA). Certified chili seeds were obtained from agricultural market.

\subsection{Preparation of Alginate-Chitosan Coated Chili Seed}

Seed coating was conducted with modification method as described by Kasra-Kermanshahi et al. (2010) and Hernandez-Suarez et al. (2011). Ten $\mathrm{mL}$ of $1 \%$ chitosan was dissolved in $10 \mathrm{~mL}^{-1}$ of $1 \%$ acetic acid and $2 \%$ calcium chloride. The $\mathrm{pH}$ was then adjusted to \pm 7 by adding $0.1 \mathrm{~N}$ calcium hydroxide. Chitinolytic bacteria were sub-cultured in nutrient agar and incubated at $30^{\circ} \mathrm{C}$ for 2 days. Sub-culture was diluted with Sterile Distilled Water (SDW) to get bacterial suspension of $\approx 10^{8}$ $\mathrm{CFU} / \mathrm{mL}$. Chili seeds were soaked in $10 \mathrm{~mL}^{-1}$ of bacterial suspension for 30 minutes. The suspension was added with $3 \mathrm{~mL}$ glycerol and finally mixed with $3 \%$ sodium alginate to have $100 \mathrm{~mL}^{-1}$ suspension. This mixture was then dropped into chitosan-calcium chloride suspension using small glass tube. Seed alginate-chitosan beads were formed as soon as the drop fell into chitosan- calcium chloride solution. The beads were put into $0.9 \%$ sodium chloride solution to make the beads more compact and then removed and agitate in SDW using stirrer to remove sodium chloride residue. The beads were air-dried and put into sterile plastic bag. Coated seeds (Fig. 1) were kept in refrigerator (ref) $\left( \pm 4^{\circ} \mathrm{C}\right)$ and at room temperature $(\mathrm{rt})\left( \pm 26-30^{\circ} \mathrm{C}\right)$ for further study.

\subsection{Control of Fusarium wilt in Alginate- Chitosan Coated Chili Seed}

Fusarium oxysporum was sub-cultured in $100 \mathrm{~mL}^{-1}$ of potato dextrose broth at $30^{\circ} \mathrm{C}$ for 10 days. Fungal subculture was blended with $500 \mathrm{~g}$ sterilized soil mixed with sterilized compost $(3: 1)$ in a $30 \times 22 \times 10 \mathrm{~cm}$ tray. Coated chili seeds were planted for 30 days in the trays covered with plastic wrap. (-) control coated seeds were treated similarly but in soil without fungal inoculation, while $(+)$ control were seed planted in fungal inoculated soil. (-) control was placed separately with others. Thirty seeds were used for each treatment. Direct observation was conducted to know number of infected seedlings.

\subsection{Measurement of Seedling Dumping off, Damping off Relative Reduction, Seedling Height and Dry-Weight}

Percentage of chili seedling damping off was observed as [number of seedling damping off/number of treated seeds $] \times 100 \%$. Damping off relative reduction (\%) was measured as [100-(percentage of damping off of treatment/percentage of damping off of $(+)$ control)] $\times 100 \%$. Plant height and dry-weight of the plant left was measured at end of study.

\subsection{Fungal re-Isolation from Infected Seedling}

Stem of infected seedling was cut by $1 \mathrm{~cm}$. The stem was surface disinfected for few seconds in $2 \% \mathrm{NaClO}$ and then rinsed thoroughly with SDW. Surface-disinfected leaves were grown on PDA for 72 hours at room temperature. Growing fungal colonies were then purified. Identification morphological characteristics such as colony, mycelia as well as shape and size of conidia under light microscopy observation were carried out.

\subsection{Assay of Bacterial Viability of Alginate- Chitosan Encapsulation}

A coated chili seed was grinded and SDW was added to make $10 \mathrm{~mL}^{-1}$ suspension. A $0.1 \mathrm{~mL}^{-1}$ of suspension was streaked on MSMC agar and incubated at room temperature. The Colony Forming Units (CFU) of microorganisms were counted to evaluate cell viability. Colony was counted for 0,15 and 30 days of seed stored at refrigerator and room temperature. 


\section{RESULTS}

\subsection{The Fusarium manifestation in chili seedling}

Fusarium wilt in chili seedling was manifested as leaf and seedling wilted with yellowing leaf followed by seedling slunted (Fig. 1). Fusarium enters through root wound and proliferates within the vascular tissue, leading to the typical wilt symptoms (Sun et al., 2011). Eventually, the whole plant wilts and dies as the disease progresses (Sun et al., 2011). Severe seedling disease resulted in stand failure as seen in this study.

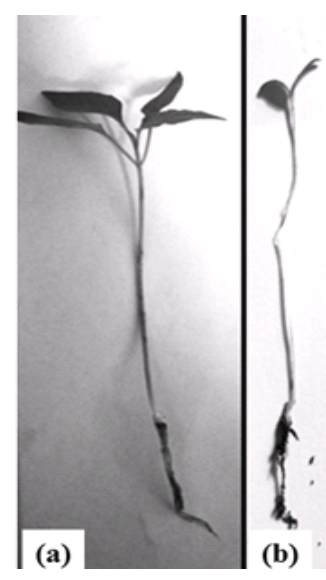

Fig. 1. (a) Healthy chili seedling and (b) Fusarium infected ones

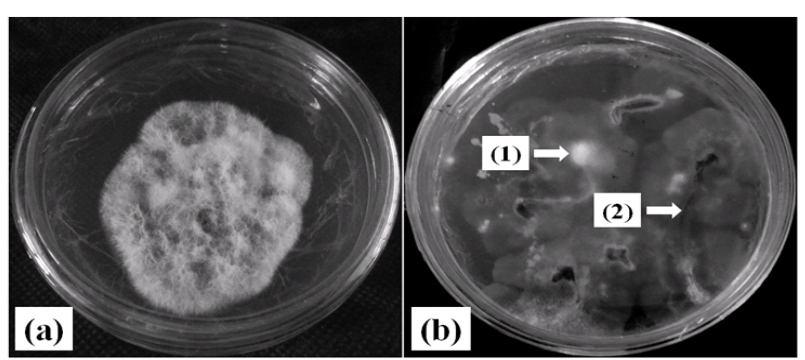

Fig. 2. F. oxysporum used as (a) Inoculant and (b) From infected seedlings: (1) white cottony hyphae and (2) infected stem of chili seedling

Re-isolation of seedling with fusarium with symptomshowed that the fungus had white cottony colony, purple at the base of medium and smooth at the surface similar to that of the fungus used as inoculant (Fig. 2). This confirmed that Fusarium used was pathogen to chili.

\subsection{Chili Damping off Suppression}

Alginate-chitosan coated seeds were planted in soil inoculated with $F$. oxysporum. Thirty days after planting seedling dumping off, seedling height and dry-weight were evaluated. The seeds planted in Fusariuminoculated soil were succeptible to Fusarium wilt showed by $(+)$ control. $(+)$ control showed that the fungi using in this study was pathogen to chili by $56.7 \%$ of total seedling wilted, implicating a partial death of chili seedlings. On the other hand, chili seeds coated with alginate-chitosan and chitinolytic bacteria obviously decreased chili damping off to some extent (Fig. 3). Enterobacter sp. BK15 seemed more active to suppress fungal growth as described by less chili damping off. Damping off relative reduction of this isolate was relatively high (70.6\%). Contrary with our study using these bacteria in controlling Ganoderma boninense of oil palm seedling Enterobacter sp. BK15 reduced less disease incidence compared to that of Bacillus sp. BK17 (Suryanto et al., 2012).

In addition to number of damping off observation, chili seedling height and dry-weight as possible manifestation of Fusarium infection were also observed (Fig. 4). Coated seed with Enterobacter sp. BK15 produced more vigorous seedling showed by its higher seedling height to $9.4 \mathrm{~cm}$ ) and dry-weight to $4.2 \mathrm{~g}$ compared to other treatments even with (-) control. In addition, direct observation of the seedling showed that the seedling was more stout and fresh. 




Fig. 3. Effect of chitinolytic bacterial treatment in alginate-chitosan encapsulation on percentage of seedling damping off caused by Fusarium wilt and damping off relative reduction

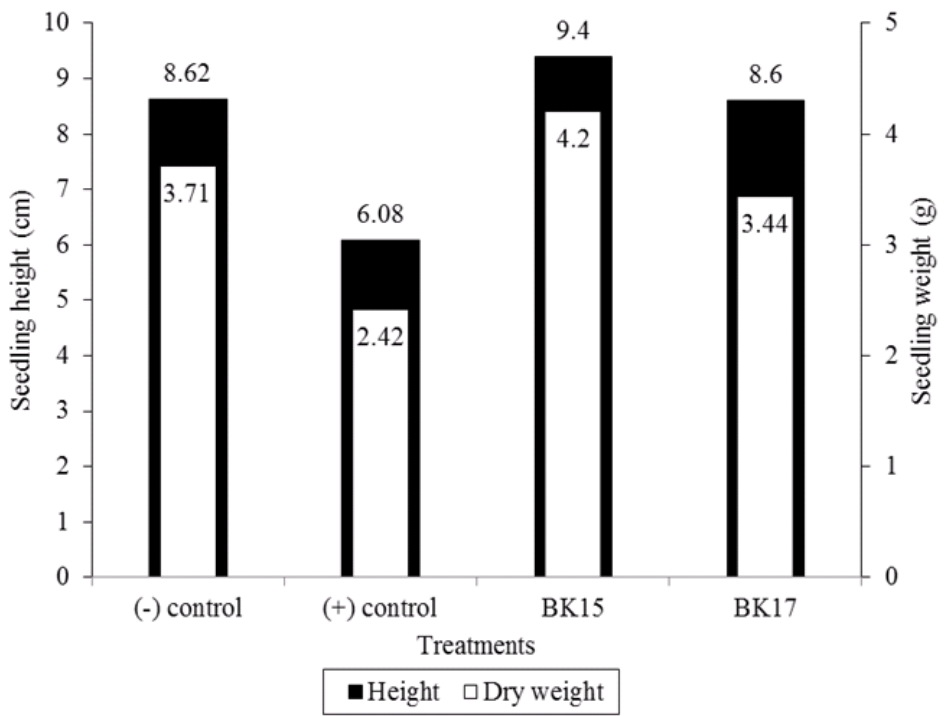

Fig. 4. Effect of chitinolytic bacterial treatment in alginate-chitosan encapsulation on chili seedling height and dry-weight

Some bacterial control agent produce plant growth regulator to increase plant performance (Forchetti et al., 2010; Hernandez-Suarez et al., 2011). Fusarium wilt caused unhealthy seedlings by reducing seedling height to $6.08 \mathrm{~cm}$ and dry-weight to $2.42 \mathrm{~g}$.

\subsection{Enumeration of Viable Bacterial Cell of Coated Chili Seed}

In order to determine cell viability of both BK15 and BK17 in alginate-chitosan encapsulation this study was conducted at different temperature up to 30 days. Cell number of both BK15 and BK17 was extremely decreased after production (Fig. 5). Decreasing pattern of both bacteria whether at refrigerator and room temperature was similar. However, the coated seed stored at refrigerator contained more viable bacterial log number of viable cell both BK15 and BK17, respectively compared to that of room temperature after 15 and 30 days of storage. 


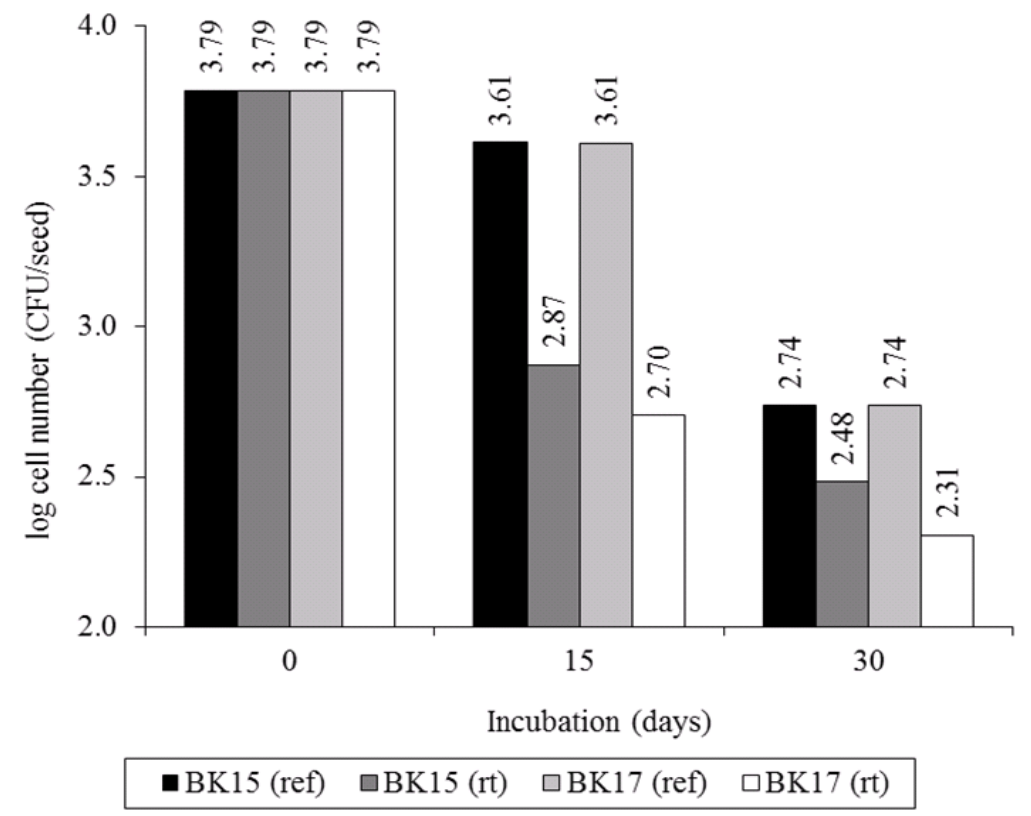

Fig. 5. Viability of chitinolytic bacterial cell of coated chili

\section{DISCUSSION}

Reisolation of Fusarium from infected seedling were to determine that the fungal was the only causal agent of the Fusarium wilt in the chili seedlings. All samples of seedling with Fusarium wilt symptoms showed that the pathogen was in the seedling. Fusarium is the most common fungi that cause such soil-borne diseases (Kucharek, 2003). These pathogens can survive long periods in the soil without a host by producing some thick-walled spores called chlamydospores which are formed within the hyphae and occur in or out of plant debris within the soil (Kucharek, 2003; Sun et al., 2011).

Enterobacter sp. BK15 and Bacillus sp. BK17 encapsulated with alginate and chitosan showed to reduce chili damping off incidence, however, BK15 was reduce more. Different effect in controlling fungal growth might be caused by different lytic enzyme produced by the isolates. Enzymes can vary both within and between microbes (Kobayashi et al., 2002).

Lytic activity of bacteria is one of a number of mechanisms that has been implicated in biocontrol for several years. Members of chitinolytic bacteria genera Bacillus, Lysinibacillus, Enterobacter, Serratia and Alcaligenes have been reported and played important role as biological control agents of plant pathogenic fungi including Fusarium oxysporum f.sp. radicislycopersici, F. oxysporum f.sp. raphani, Phytophthora cinnamomi, $P$. nicotianae and Rhizoctonia solani
(Kavraulakis et al., 2010). Our previous studies also showed that chitinolytic bacterial isolates reduce disease incidence of $G$. boninense in oil palm seedling (Suryanto et al., 2012) and inhibited some plant pathogenic fungal growth (Suryanto et al., 2011).

Fungal cell wall usually is composed not only with chitin but also with other sugar such as $\beta-1,3$ glucan which binds to chitin in amorf structure. Chitinase and $\beta$ glucanase activity was detected in all bacterial strains exhibiting in vitro antagonistic activity against soil-borne plant pathogens (Kavraulakis et al., 2010). Therefore, chitinase and $\beta$-glucanase produced by the isolates should be considered as enzyme responsible in lysing chitin polymer of Fusarium hyphae.

Many reported that antagonistic bacteria contribute to plant performance and vigor. Our study showed that Enterobacter sp. BK15 application produced higher seedling height and dry-weight. Enterobacter cancerogenus MSA2 showed overall plant growth promotion of Jatropa curcas by producing metabolites such as 1-aminocyclopropane-1-carboxylic acid deaminase, phytase, indole acetic acid and siderophore (Jha et al., 2011). Enterobacter has also been reported to control pathogenic fungi (Okamoto et al., 2000; Slininger et al., 2004). The use of antagonist rhizobacteria belonging to Bacillus genus showed to stimulate plant growth and to increase crop yield of tomato (Hernandez-Suarez et al., 2011). Endophytic 
bacterial strains SF2 $(99.9 \%$ homology with Achromobacter xylosoxidans) and SF3 and SF4 (99.9\% homology with B. pumilus) enhanced growth of sunflower seedlings under water stress and inhibited growth of pathogenic fungi (Forchetti et al., 2010). Tariq et al. (2009) reported the dual role of Pseudomonas spp. in plant-growth promotion and disease control. $P$. aeruginosa inhibited the radial growth of root rotting fungi Macrophomina phaseolina, Rhizoctonia solani, F. solani and $F$. oxysporum and caused significant suppressive effect on root rotting fungi and root knot nematode infecting chili roots. Some $P$. aeruginosa strains also showed to increase the plant height and fresh shoot weight by producing indole acetic acid.

Encapsulation maintains bacterial viability and stability for prolong term storage (Rokka and Rantamaki, 2010). Our study showed that the bacterial population in chili beads dropped rapidly after production both storage at refrigerator and room temperature. However, inactivation of cell during refrigerator storage prolonged self-live cells. In contrast with our study, encapsulation of isolated bacterium with alginate and chitosan showed higher stability during 1 month of storage (KasraKermanshahi et al., 2010).

Although our initial bacterial culture was taken from 2-days old culture, physiological status of both bacteria was not confirmed before producing alginate-chitosan encapsulation. Vegetative cells are more susceptible to environmental stress compare to endospores. However, Chumthong et al. (2008) observed that application of an equivalent number of un-formulated endospores resulted in much loss of the bacterial endospores even 1 day after application. Furthermore chili bead producing by method described seemed not to uniform. Next study needs to be conducted to know the effect of encapsulation on bacteria of varied physiological status i.e., log phase, lag phase and endospore, to examine consistency of the bacteria in suppressing damping off after given storage time and to produce more uniform bead.

\section{CONCLUSION}

Chitinolytic bacterial isolates, Enterobacter sp. BK15 and Bacillus sp. BK17, in alginate-chitosan coated seeds suppressed chili damping off caused by $F$. oxysporum. No different effect was observed on chili seedling height and dry-weight treated with bacterial isolates to treatment with no bacterial and fungal inoculation, but differed with those of fungal inoculation only. Cell viability of the isolates decreased significantly in 30 days of storage both at refrigerator and room temperature. However, cell stored at refrigerator was more viable rather than that of room temperature.

\section{ACKNOWLEDGEMENT}

We would like to thank to DITLITABMAS, Directorate General of Higher Education, Indonesian Ministry of Education and Culture for supporting this research.

\section{REFERENCES}

Anitha, A. and M. Rabeeth, 2010. Degradation of fungal cell walls of phytopathogenic fungi by lytic enzyme of Streptomyces griseus. Afr. J. Plant Sci., 4: 61-66.

Bashan, Y., 1998. Inoculants of plant growth-promoting bacteria for use in agriculture. Biotechnol. Adv., 16: 729-770. DOI: 10.1016/S0734-9750(98)00003-2

Chumthong, A., M. Kanjanamaneesathian, A. Pengnoo and R. Wiwattanapatapee, 2008. Water-soluble granules containing Bacillus megaterium for biological control of rice sheath blight: Formulation, bacterial viability and efficacy testing. World J. Microb. Biotechnol., 24: 2499-2507. DOI: 10.1007/s1 1274-008-9774-7

Compant, S., B. Duffy, J. Nowak, C. Clement and E.A. Barka, 2005. Use of plant growth-promoting bacteria for biocontrol of plant diseases: Principles, mechanisms of action and future prospects. Appl. Environ. Microbiol., 71: 4951-4959. PMID: 16151072

Forchetti, G., O. Masciarelli, M.J. Izaguirre, S. Alemano and D. Alvarez et al., 2010. Endophytic bacteria improve seedling growth of sunflower under water stress, produce salicylic acid and inhibit growth of pathogenic fungi. Curr. Microbiol., 61: 485-493. PMID: 20383767

Gangadara, N.B., Saifulla, R. Nagaraja and M.K. Basavaraja, 2010. Biological control of Fusarium oxysporum $\mathrm{f}$. Sp. Vanillae, the casual agent of stem rot of vanilla in vitro. Int. J. Sci. Nat., 1: 259-261.

Gupta, S., A. Dubey and T. Singh, 2011. Fusarium semitectum as a dominant seed-borne pathogen in dalbergia sissoo roxb., its location in seed and its phytopathological effects. Ind. J. Fundamen. Appl. Life Sci., 1: 5-10.

Hernandez-Suarez, M., F.D. Hernandez-Castillo, G. Gallegos-Morales, R.H. Lira-Saldivar and R. Rodriguez-Herrera et al., 2011. Biocontrol of soil fungi in tomato with microencapsulates containing Bacillus subtilis. Am. J. Agric. Biol. Sci., 6: 189195. DOI: 10.3844 /ajabssp.2011.189.195

Jha, C.K., B. Patel and M. Saraf, 2011. Stimulation of the growth of Jatropha curcas by the plant growth promoting bacterium Enterobacter cancerogenus MSA2. World J. Microbiol. Biotechnol., 28: 891-89. DOI: $10.1007 / \mathrm{s} 11274-011-0886-0$ 
Kasra-Kermanshahi, R., J. Fooladi and S. Peymanfar, 2010. Isolation and microencapsulation of Lactobacillus spp. from corn silage for probiotic application. Iran. J. Microbiol., 2: 98-102.

Kavraulakis, N., S. Ntougias, M.I. Besi, P. Katsou and A. Damaskinou et al., 2010. Antagonistic bacteria of composted agro-industrial residues exhibit antibiosis against soil-borne fungal plant pathogens and protection of tomato plants from Fusarium oxysporum f.sp. radicis-lycopersici. Plant Soil., 333: 233-247. DOI: 10.1007/s11104-010-0338-x

Kobayashi, D.Y., R.M. Reedy, J.A. Bick and P.V. Oudemans, 2002. Characterization of a chitinase gene from Stenotrophomonas maltophilia strain $34 \mathrm{~S} 1$ and its involvement in biological control. Applied Environ. Microbiol., 68: 1047-1054. DOI: 10.1128/AEM.68.3.1047-1054.2002

Kucharek,T., 2003. Control of soilborne plant diseases of vegetables in transplant production systems, plant protection pointer. University of Florida. Gainesville.

Okamoto, H., M. Sato, Y. Miyata, M. Yoshikawa and M. Isaka, 2000. Biocontrol of Phytophthora root rot of angelica trees by Enterobacter cloacae and Serratia ficaria Strains. Gen. Plant Pathol., 66: 86-94. DOI: 10.1007/PL00012927

Rokka, S. and P. Rantamaki, 2010. Protecting probiotic bacteria by microencapsulation: Challenges for industrial applications. Eur. Food Res. Technol., 231: 1-12.
Slininger, P.J., K.D. Burkhead and D.A. Schisler, 2004. Antifungal and sprout regulatory bioactivities of phenylacetic acid, indole-3-acetic acid and tyrosol isolated from the potato dry rot suppressive bacterium Enterobacter cloacae S11:T:07. J. Ind. Microbiol. Biotechnol., 31: 517-524. PMID: 15558349

Sun, J.B., M. Peng, Y.G. Wang, P.J. Zhao and Q.Y. Xia, 2011. Isolation and characterization of antagonistic bacteria against fusarium wilt and induction of defense related enzymes in banana. Afr. J. Microbiol. Res., 5: 509-515.

Suryanto, D., N. Irawati and E. Munir, 2011. Isolation and characterization of chitinolytic bacteria and their potential to inhibit plant pathogenic fungi. Microbiol. Indones., 5: 144-148. DOI: 10.5454/mi.5.3.8

Suryanto, D., R.H. Wibowo, E.B.M. Siregar and E. Munir, 2012. A possibility of chitinolytic bacteria utilization to control basal stems disease caused by Ganoderma boninense in oil palm seedling. Afr. J. Microbiol. Res., 6: 2053-2059. DOI: 10.5897/AJMR11.1343

Tariq, S., R. Khan, V. Sultana, J. Ara and S. EhteshamulHaque, 2009. Utilization of endo-root fluorescent Pseudomonas of chilli for the management of root diseases of chilli. Pak. J. Bot., 41: 3191-3198. 